\title{
AN EVALUATION AND PARTIAL CHARACTERIZATION OF A BACTERIOCIN PRODUCED BY LACTOCOCCUS LACTIS SUBSP LACTIS ST1 ISOLATED FROM GOAT MILK
}

\section{Parinaz Taheri $^{1^{*}}$, Nasrin Samadi², Mohammad Reza Ehsani ${ }^{1}$, Mohammad Reza Khoshayand ${ }^{2}$, Hossein Jamalifar ${ }^{2}$}

${ }^{1}$ Department of Food Science and Technology, Faculty of Agriculture and Natural Resources, Science and Research Branch, Islamic Azad University, Tehran, Iran; ${ }^{2}$ Department of Drug and Food Control, Faculty of Pharmacy and Pharmaceuticals Quality Assurance Research Center, Tehran University of Medical Sciences, Tehran, Iran.

Submitted: March 24, 2011; Returned to authors for corrections: April 23, 2012; Approved: June 07, 2012.

\begin{abstract}
A bacteriocin-like inhibitory substance producing Lactococcus lactis subsp lactis strain, ST1, isolated from goat milk of Iranian origin and with broad spectrum of activity and desirable technical properties was used for evaluating some futures of bacteriocin inhibitory activity. Cell growth and bacteriocin production studies were carried out in MRS medium incubated statically under uncontrolled $\mathrm{pH}$ condition. The antibacterial activity presented a primary metabolite pattern and showed a rapid decrease at the stationary phase. Microaerobiosis and capnophily growth conditions resulted in higher bacteriocin production while aerobiosis showed negative effect on both cell growth and bacteriocin production. Bacteriocin production, on the other hand, was favored in MRS broth $(\mathrm{pH} ; 6.5)$ inoculated with $0.1 \mathrm{ml} \mathrm{l}^{-1}$ fresh culture when incubation was carried out at $30{ }^{\circ} \mathrm{C}$. This indicated that the conditions resulted in higher levels of growth were frequently favoring bacteriocin production by ST1 as well. Decrease in activity, at the stationary growth phase, was much pronounced in favored growth condition. Nutrient depletion, deferent effect of low $\mathrm{pH}$ on bacteriocin production and/or protein degradation seemed more responsible for this phenomenon. The study also provided further data on new method for bacteriocin release from the cell wall of producer. It was clearly shown that both heating and ultrasound shock for $5 \mathrm{~min}$ at $\mathrm{pH} 2$ could increase bacteriocin activity significantly. The release was more pronounced in the presence of $0.5 \%$ Tween 80 .
\end{abstract}

Key words: Lactococcus lactis subsp lactis ST1, Bacteriocin production, Environmental factors, Bacteriocin release, Ultrasound shock

\section{INTRODUCTION}

The growing demands of less-processed and more natural and safe food products have led to considerable interest in the application of natural antimicrobial substances as food preservatives. Bacteriocins, the focus of abundant studies in this concept, are defined as ribosomally synthesized, extracellular, antibacterial peptides that are generally active against closely related species to the producer microorganisms (11). Although many bacteria are reported as potent bacteriocin

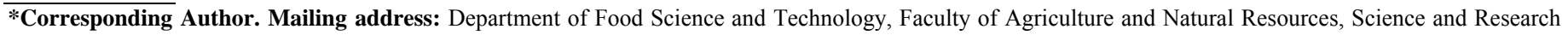
Branch, Islamic Azad University, Tehran, Iran.; Tel.: +1 7789280089.; E-mail: taheriparinaz@yahoo.com 
producers, bacteriocins produced by lactic acid bacteria (LAB) are of particular interest $(11,24)$. Among all, several strains of Lactococcus lactis subsp lactis produced nisin with desirable stability and a broad spectrum of activity not only against closely related species but also towards some food-borne pathogens such as Listeria monocytogenes. Nisin has been approved as a GRAS food preservative and became as the most widely studied bacteriocin $(1,10,20)$.

For effective application and the highest production of bacteriocins understanding the relation between cell growth and bateriocin production sound necessary. It has been reported that nisin biosynthesis occurs during the exponential growth phase affected by several cultural and environmental factors (1, 23, 26). Additionally, a dramatic decline of activity at the final stages of exponential growth phase was demonstrated for nisin and some other bacteriocins (1, 10, 22, 32, 33). As a result, investigating the metabolic features of bacteriocin biosynthesis and understanding the most effective factors on bacteriocin production is significant in order to improve the production rate. Additionally, creating the optimum conditions for the maintenance of the activity seem to be economically significant.

Studies have demonstrated that the bacteriocin molecules are, in general terms, adsorbed by the producer cell $(5,36)$. Releasing bacteriocin molecules from the surface of the producer is an important preliminary step to achieve high quantity of purified bacteriocins for production or further characterizing. Accordingly, various researches based on different techniques had been investigated. Acid extraction (5, 36) was reported as effective method for bacteriocin release from the producer cells. The positive effect of ethanoltreatment and Tween-treatment during fermentation on desorption of bacteriocin molecules was reported by Callewaert et al. (8) and Aymerich et al. (2). Furthermore, a combination of $\mathrm{pH}$ treatment with heat treatment after fermentation, seem responsible for an increase in soluble activity (2).

Apart from effective parameters on the bacteriocin connections to the cell wall of the producer, each change in the structure and functionality of cell wall can be effective on release of bacteriocin. Dmitriev et al. (15) claimed that the functionality of the cell wall of bacteria can be influenced by every kind of shock that can be due to improvement or damage of its normal physiological and vital activities. Ultrasound has been introduced as an effective factor in damaging the cell wall of the micro-organisms by causing cavitations in aqueous solutions (28). This has inspired and partly assisted the hypothesis for evaluation the effect of ultrasound shock on the bacteriocin release.

In our study the kinetics of cell growth and bacteriocin production by an isolated LAB strain from Iranian milk samples are studied. It is shown that bacteriocin production and maintenance is affected by different environmental factors such as atmospheric growth condition. Furthermore, the effect of different treatments such as ultrasound shock on bacteriocin desorption from the cell wall of the producer is evaluated, and the best method for bacteriocin release was introduced.

\section{MATERIALS AND METHODS}

\section{Bacterial strains and culture media}

In previous studies, bacteriocin producing strains were detected in fermented and non-fermented dairy samples collected from central regions of Iran and the isolated strain showing prominent inhibitory spectrum with highlighted technical properties (heat stability, stability over a wide range of $\mathrm{pH}$ and viability over time) was genetically identified based on the sequence of $16 \mathrm{~S}$ rDNA and selected for further studies.

The selected producer used in this survey as bacteriocin producer, was grown in De Man Rogosa \& Sharpe (MRS) broth at $37^{\circ} \mathrm{C}$, and Micrococcus luteus, which was applied as an indicator strain, was grown in CASO medium at $30^{\circ} \mathrm{C}$. Bacterial stocks were maintained frozen at $-70{ }^{\circ} \mathrm{C}$ in $25 \%(\mathrm{v} / \mathrm{v})$ glycerol. The cells were propagated twice in appropriate broth media for $20 \mathrm{~h}$ before application. Adding 15 and $10 \mathrm{~g} \mathrm{l}^{-1}$ agar to the broth media, respectively, led the experiment to obtain 
agar and soft agar afterward. All chemical reagents and enzymes were gained from Sigma-Aldrich (St. Louis, MO, USA), and the culture media used in the experiment were supplied by MERCK (Germany).

\section{Cell growth and Bacteriocin production}

Bacterial growth and BLIS production were studied at 37 ${ }^{\circ} \mathrm{C}$ in 250-ml Erlenmeyer flasks containing $100 \mathrm{ml}$ of MRS broth medium prepared from single ingredients (12). Overnight culture of ST1 was inoculated into MRS broth $\left(1 \mathrm{ml} \mathrm{l}^{-1}\right)$ to reach the initial cell density of approximately $10^{6}$ c.f.u ml$~^{-1}$. Incubation was then carried out statically under uncontrolled $\mathrm{pH}$ condition.

Taking atmospheric experiments into account, aerobiosis as well as microaerobiosis (MART system, $5 \% \mathrm{CO}_{2}, 5.9 \% \mathrm{O}_{2}$, $7.2 \% \mathrm{H}_{2}, 79 \% \mathrm{~N}_{2}$ ) and capnophily (candle jar) conditions were tested. Samples were taken aseptically every $2 \mathrm{~h}$ and changes in bacteriocin activity ( $\mathrm{AU} \mathrm{ml} \mathrm{m}^{-1}$ ), cell count (c.f.u ml ${ }^{-1}$ ) and $\mathrm{pH}$ (pH 211, HANNA instrument, Woonsocket, RI, USA) were determined for $20 \mathrm{~h}$.

Bacteriocin activity of the cell-free supernatants (CFS) was assayed by agar well diffusion assay (AWDA) (3). Accordingly, cultures were centrifuged at $5,000 \times \mathrm{g}$ for $15 \mathrm{~min}$, and the obtained cell-free culture supernatants were, first, adjusted to $\mathrm{pH} 6.5$ with $1 \mathrm{~mol}^{-1} \mathrm{NaOH}$, then, treated with catalase ( $1 \mathrm{mg} \mathrm{ml}^{-1}$, Bovine Catalase, EC1.11.1.6), and finally sterilized by microfiltration $(0.22-\mu 1$ size; Millipore Co., Bedford, MA, USA). The samples were transferred into holes of $6 \mathrm{~mm}$ in diameter while they were drilled into soft CASO agar plates which were seeded with $M$. luteus suspension (equivalent to $1.5 \times 10^{8}$ c.f.u ml ${ }^{-1}$ ) using a sterile cotton swab. For the pre-diffusion phase, the plates were initially kept at $4^{\circ} \mathrm{C}$ for $2 \mathrm{~h}$, and then incubated for $16 \mathrm{~h}$ at $30{ }^{\circ} \mathrm{C}$. Antimicrobial activity was detected by a clear zone around a test well. Proteinase K, trypsin and pepsin were afterwards used to test the protein nature of the antimicrobial activity. Each one was added to the cell-free supernatant at a final concentration of 1 $\mathrm{mg} / \mathrm{ml}$. After $2 \mathrm{~h}$ incubation at $37^{\circ} \mathrm{C}$, the reaction was stopped by heating at $100{ }^{\circ} \mathrm{C}$ for $3 \mathrm{~min}$. The inhibitory activity was then assayed by AWDA.

Antimicrobial activity was expressed as arbitrary units (AU) per $\mathrm{ml}$ and for this assessment the resulting supernatant sample was serially diluted twofold with sterilized phosphate buffer $\left(0.1 \mathrm{~mol} \mathrm{l}^{-1}, \mathrm{pH} 6.5\right)$ and the antimicrobial activity of each diluted sample was detected according to AWDA. One AU has been defined as the reciprocal of the highest dilution showing a clear zone of growth inhibition.

For evaluating the cell counts (c.f.u ml ${ }^{-1}$ ), plate count method was used through the application of MRS agar incubated at $30^{\circ} \mathrm{C}$ for $48 \mathrm{~h}$.

\section{Effects of inoculum size, $\mathrm{pH}$ and incubation temperature on cell growth and BLIS production}

The kinetic of growth and bacteriocin production of $L$. lactis subsp lactis ST1 was studied in separate set of experiments in MRS flask cultures and the effects of initial $\mathrm{pH}$ ranges (between 4.5 and 8.5); and different inoculum levels $\left(0.1,1.0\right.$ and $\left.10.0 \mathrm{ml} \mathrm{l}^{-1}\right)$ were investigated.

To study the effect of $\mathrm{pH}$, the initial $\mathrm{pH}$ of MRS medium was adjusted in the $\mathrm{pH}$ range of 4.5 to 8.5 with $5 \mathrm{~mol}^{-1} \mathrm{HCl}$ or 5 mol $1^{-1} \mathrm{NaOH}$. An overnight culture of ST1 strain was used to inoculate $200 \mathrm{ml}$ of MRS broth medium $\left(10^{6}\right.$ c.f.u ml $\left.{ }^{-1}\right)$, and incubation was carried out at $37^{\circ} \mathrm{C}$.

To evaluate the effect of inoculum size on the level of bacteriocin production $0.1,1.0$ or $10.0 \mathrm{ml} \mathrm{l}^{-1}$ inoculum from an overnight culture of ST1 strain in MRS broth (with $10^{9}$ c.f.u $\mathrm{ml}^{-1}$ cell concentration) was added into $200 \mathrm{ml}$ MRS broth ( $\mathrm{pH}$ 6.2) to reach a final concentration of $10^{5}, 10^{6}$ or $10^{7}$ c.f.u ml ${ }^{-1}$, respectively and the cultures were incubated at $37^{\circ} \mathrm{C}$.

To estimate the effect of temperature, MRS broth ( $\mathrm{pH}$ 6.2) was inoculated with the producer suspension and incubated at 25, 30 and $37^{\circ} \mathrm{C}$.

All flasks were incubated for $20 \mathrm{~h}$ without agitation, and changes in cell counts (c.f.u $\mathrm{ml}^{-1}$ ) and production of bacteriocin $\left(\mathrm{AU} \mathrm{ml} \mathrm{m}^{-1}\right)$ were determined every $2 \mathrm{~h}$. 


\section{Bacteriocin release from the surface of producer cells}

Studies have shown that the fermentation broth can be best collected as soon as maximum activity is reached (13). Therefore, for evaluating the effect of ultrasonic waves, heat treatment and Tween 80 at different $\mathrm{pH}$ conditions on physical desorption of the bacteriocin from the cell wall of the producer (ST1), a 14 h culture was obtained as described above and split up into two parts; Tween80 (0.5\%) was added into one part and the other remained intact. Each sample was then divided in $10 \mathrm{ml}$ aliquots, adjusted to $\mathrm{pH} 2.0,4.0$ and 6.0 using sterile $0.02 \mathrm{~N} \mathrm{HCl}$ and heat treated at $100{ }^{\circ} \mathrm{C}$ or exposed to the ultrasound shock for 5, 10 and $15 \mathrm{~min}$ in the constant frequency of $28 \mathrm{KHz}$ (Starsonic 60, GALLAY, Melbourn) at room temperature.

Thus, both the initial bacteriocin activity of ST1 culture before treatment (BT) and the activity of treated sample after each treatment (AT) were determined according to AWDA. AWDA assessment was performed after removing the producer cells from the culture and readjustment of the $\mathrm{pH}$ to 6.5 . Thus, the percentage of desorption was calculated as: [(AT-BT)/ BT] $\times 100$.

\section{Statistical analysis}

For estimating the effect of different parameters on cell count, bacteriocin activity and changes in $\mathrm{pH}$, each experiment was repeated three times and the mean was reported. ANOVA with a 99\% confidence levels was used for analyzing the variances and detecting the significant or nan-significant differences. For gaining and measuring the regression equation and its related statistical results Microsoft Excel Software 7 was applied.

\section{RESULTS AND DISCUSSION}

\section{Screening and identification of antagonistic bacterium}

Among all five LAB possessed bacteriocin like inhibitory activities isolated from Iranian milk products in previous studies, Lactococcus lactis subsp lactis ST1 from goat milk showed prominent antimicrobial activities in preliminary tests. The activities included the broad spectrum of activity against Gram-positive (such as S. aureus and L. monocytogenes) and some Gram-negative indicators (like E. coli and $S$. typhimurium), stability over a wide range of $\mathrm{pH}$ (2-11), stability towards different heat treatment (partially inactivated at $100{ }^{\circ} \mathrm{C}$ for $60 \mathrm{~min}$ ) and good viability over time (100\% active after 4 weeks storage at $-20^{\circ} \mathrm{C}$ ). The antimicrobial activity of cell free supernatant ST1 was completely inactivated towards all three proteolytic enzymes tested. This indicated the proteinaceous nature of the antimicrobial compound produced by ST1. The strain was further deposited in GenBank under the accession number GU5235466 as a bacteriocin producer strain which was applied in this study.

\section{Cell growth and bacteriocin production}

Figure 1 illustrates cell growth, $\mathrm{pH}$ variation, and bacteriocin production for L. lactis subsp lactis ST1 in MRS broth under different atmospheric growth condition.

In all tested conditions, the exponential phase started after $2 \mathrm{~h}$ and the maximum biomass was achieved after about $14 \mathrm{~h}$ of incubation which remained constant up to the end of incubation time. In this context, the $\mathrm{pH}$ decreased rapidly during $12 \mathrm{~h}$ of exponential growth phase and the rate of $\mathrm{pH}$ drop decreased at the early stationary phase. In addition to these findings, the bacteriocin production started as soon as the cells entered the exponential phase. The bacteriocin activity rose rapidly and the maximum activity was attained after about $12-14 \mathrm{~h}$ incubation. As shown in Figure 1 the maximum bacteriocin production was achieved at the end of exponential growth phase when the intensity of cell growth and $\mathrm{pH}$ drop decreased.

No significant differences were observed in cell growth, bacteriocin production and $\mathrm{pH}$ decrease, when ST1 was grown in capnophilic and microaerophilic growth conditions (Figure 1a and b). Cell growth and bacteriocin production were favored in these two conditions while lower growth and activity were observed in aerobiosis. Cell growth was restricted to 8.89 c.f.u $\mathrm{ml}^{-1}$ at the end of incubation time in aerobiosis while, it was 
recorded as 9.62 and 9.42 c.f.u $\mathrm{ml}^{-1}$ in microaerophilic and capnophilic condition, respectively. The maximum activity was also detected after $12 \mathrm{~h}$ of incubation in candle jar as well as microareophilic growth conditions by $320 \mathrm{AU} \mathrm{ml}^{-1}$ (Fig la and $\mathrm{b}$, respectively), but under aerobic condition the activity just reached $160 \mathrm{AU} \mathrm{ml}^{-1}$ after $12 \mathrm{~h}$ of incubation (Fig 1c). Incubation under aerobic condition resulted in final $\mathrm{pH} 4.6$ after $20 \mathrm{~h}$ incubation that is much higher than 3.9 and 4.1 in the case of microaerophilic and capnophilic condition. Oxidative stress could, in general, slightly impact the growth of LAB, since they are defined as aerotolerant microorganisms though different behavior had been detected for bacteriocin production in various atmospheric incubation conditions $(7,17,19,27)$. Hirsch (17) suggested strict anaerobiosis as the suitable conditions for bacteriocin production. Leroy et al. (19) also reported no interfering effect of oxygen on cell growth and bacteriocin production of E. faecium RZS C5. It is in contrast to Cabo et al. (7) who found that aeration is essential for optimum bacteriocin production. Sousa et al. (27) also showed the negative effect of anaerobiosis on antagonism expression. The differences between various tested strains may be the reason for these discrepancies.

The specified pattern of cell growth and bacteriocin production for ST1 indicated that the produced bacteriocin is a primary metabolite. Similar results have been reported for bacteriocins produced by Lactobacillus helveticus G51 (6), and Lactococcus lactis subsp. lactis (4). The activity remained constant for about $2 \mathrm{~h}$ in all tested conditions and decreased afterwards when the cells entered the stationary phase. A similar decrease in activity was shown in previous studies for nisin (1) and some other bacteriocins such as bacteriocin A164 (10), bacteriocin GM005 (22), bacteriocin AMA-K (32) and bacteriocin ST13BR (33). The reduction in activity was clearly shown in all incubation conditions. Since higher intensity in this reduction of activity was observed in microaerophilic and capinophilic growth condition (around 88 and $93 \%$ reduced activity, respectively), it can be concluded that favorable growth condition may be responsible for this phenomenon. On the other hand, incubation under aerobiosis preserved the activity with only $75 \%$ reduction, up to the end of incubation time.

This loss of activity has been related to proteolytic degradation, protein aggregation, and/or adsorption to cell surface of the producer while adsorption phenomenon has been considered more responsible by some authors $(13,20,22,32)$. But, bacteriocin release from the surface of producer at acidic conditions has been reported previously $(5,36)$ and on the basis of these findings it is expected that by reducing the $\mathrm{pH}$ at the end of fermentation, bacteriocin desorption should be favored and hence a higher activity would be detected. However, reduction of activity was observed at the end of fermentation and by higher acidification under microaerophilic and capinophilic growth conditions lower bacteriocin activity was observed at the end of fermentation. Thus, decrease in activity cannot be explained by bacteriocin adsorption. On the other hand, there is no conclusive study indicating the presence of nisin-specific protease (nisinase) in L. lactis that can describe the reduction phenomenon (1). This reduction in activity might be related to the deterrent effect of low $\mathrm{pH}$ or nutrient depletion on bacteriocin production. Zamfir et al. (37) also related the reduction of cell growth and bacteriocin production of L. acidophilus IBB 801 to the lactic acid accumulation and hence low $\mathrm{pH}$ or an exhausted energy source at the end of fermentation. Wolf-Hall et al. (35) also claimed that the shortage of certain nutrients critical for bacteriocin production could be responsible for this phenomenon during the latter stages of fermentation.

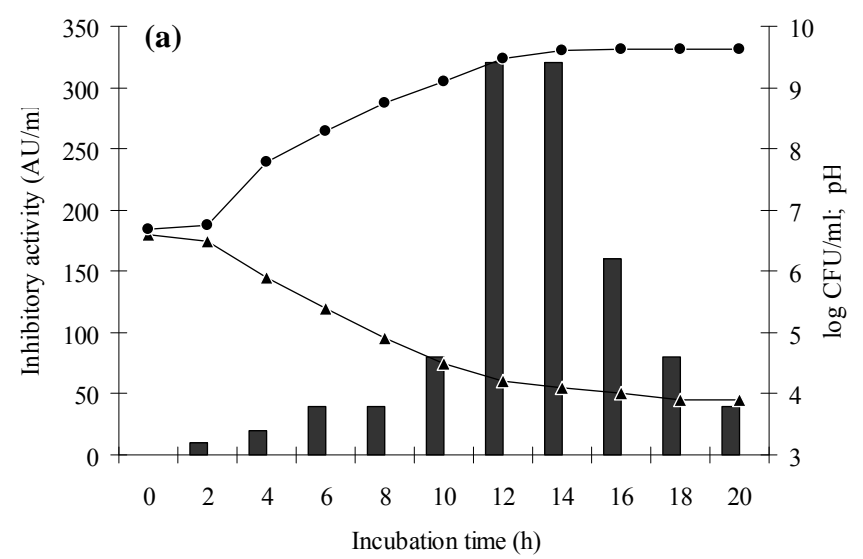



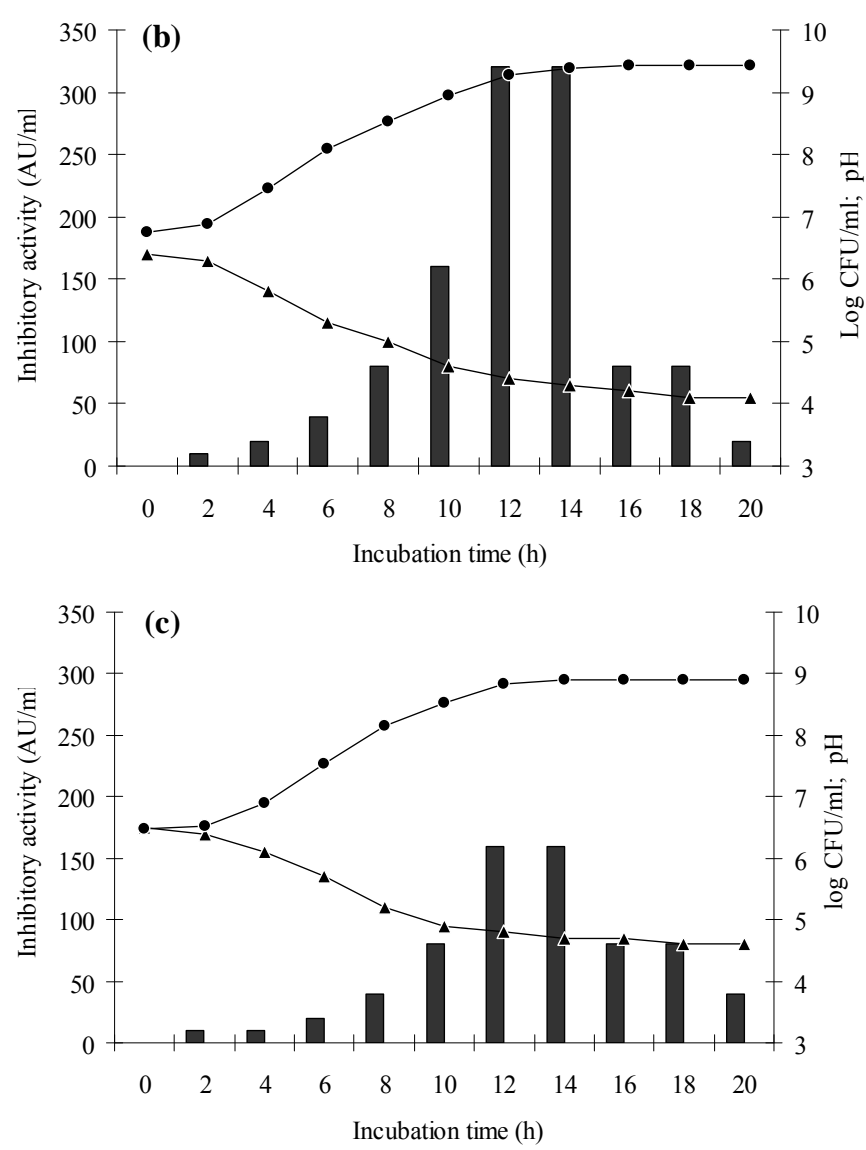

Figure 1. Time course of growth and BLIS production by $L$. lactis subsp lactis ST1, in MRS broth at $37{ }^{\circ} \mathrm{C}$ under microaerobic (a); capnophilic (b) and aerophilic (c) growth condition. Viable cell numbers ( $\log$ c.f.u $\mathrm{ml}^{-1}, \mathbf{-}-$-); BLIS activity (AU ml $\left.{ }^{-1},-\mathbf{-}-\right)$; pH (-@-). Data are average values of at least three replicates.

\section{Cell growth and bacteriocin production at different initial} pHs, inoculum sizes, and incubation temperatures

As shown in Figure 2, increasing the initial $\mathrm{pH}$ from 4.5 to 6.0 enhanced cell growth and bacteriocin production. Maximum bacteriocin activity (640 AU/ml) was obtained when the $\mathrm{pH}$ reached 6.5, followed by when it reached 7.0 and 7.5. Slight reductions in growth and activity were detected when the $\mathrm{pH}$ reached 8.5 . The broadest range of stability in antimicrobial activity was achieved at $\mathrm{pH} 6.5$ and cell growth was also among the highest (Fig. 2d) while, no activity was recorded at $\mathrm{pH} 4.5$ (data not shown). By increasing the initial
$\mathrm{pH}$, the exponential growth phase was reduced.

From the results obtained and other surveys by Aymerich et al. (2) (enterocins A and B), Todorov and Dicks (31) (bacteriocin ST23LD) and Todorov and Dicks (29) (bacteriocin ST34BR) it can be concluded that bacteriocin production was mostly achieved at initial $\mathrm{pH}$ values between 6.5 and 7.5. There are some evidences also demonstrating the inhibitory effect of low initial $\mathrm{pH}$ on both cell growth and bacteriocin production by Aymerich et al. (2), Todorov and Dicks (31), and Powell et al. (23). Despite similar reports for the effect of initial $\mathrm{pH}$ on bacteriocin production Mitra et al. (21) observed a distinct behaviour for L. lactis CM1 and claimed that under $\mathrm{pH} 11.0$ the activity of the nisin production was more significant than the initial $\mathrm{pH}$ of 6.5 .
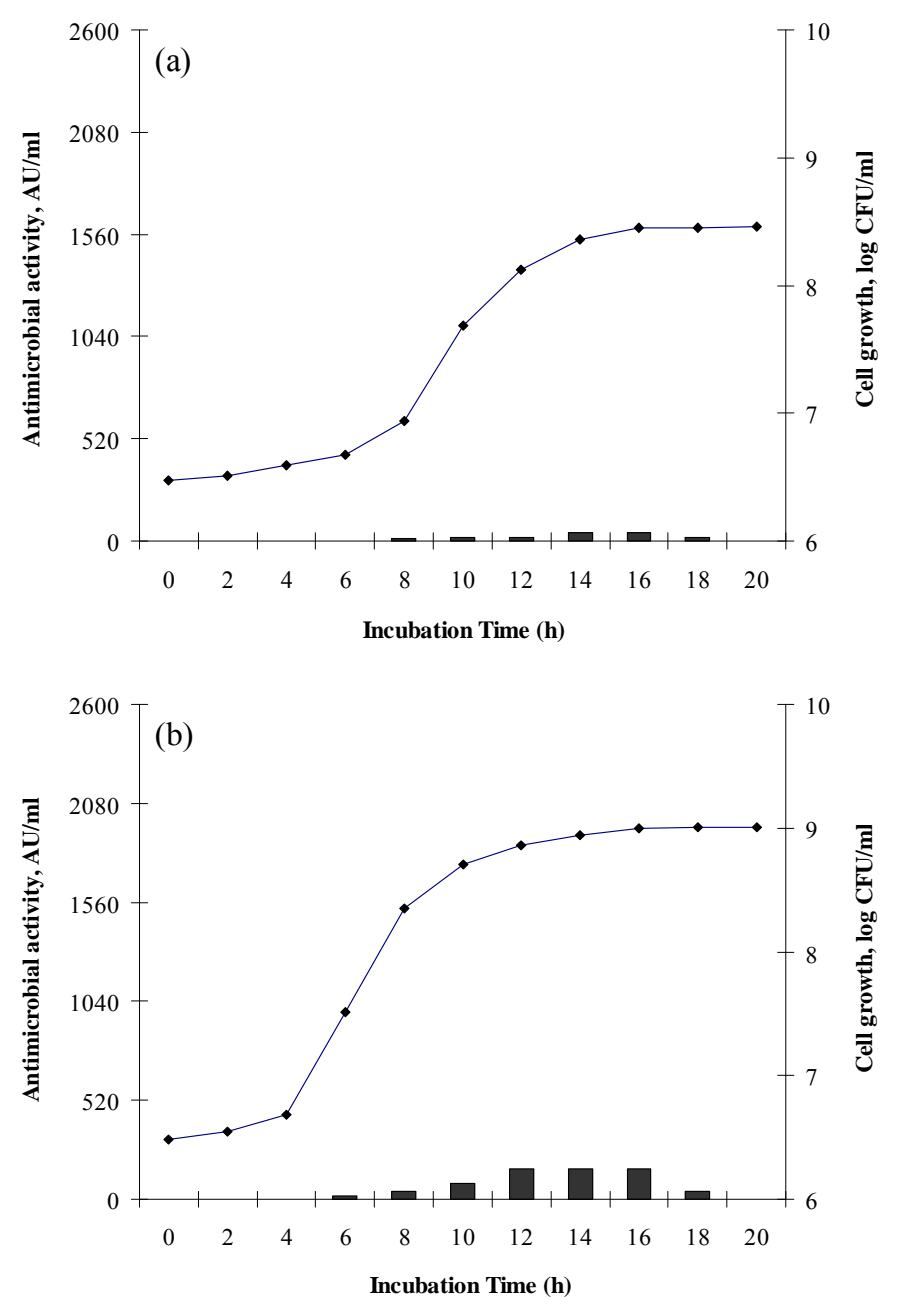

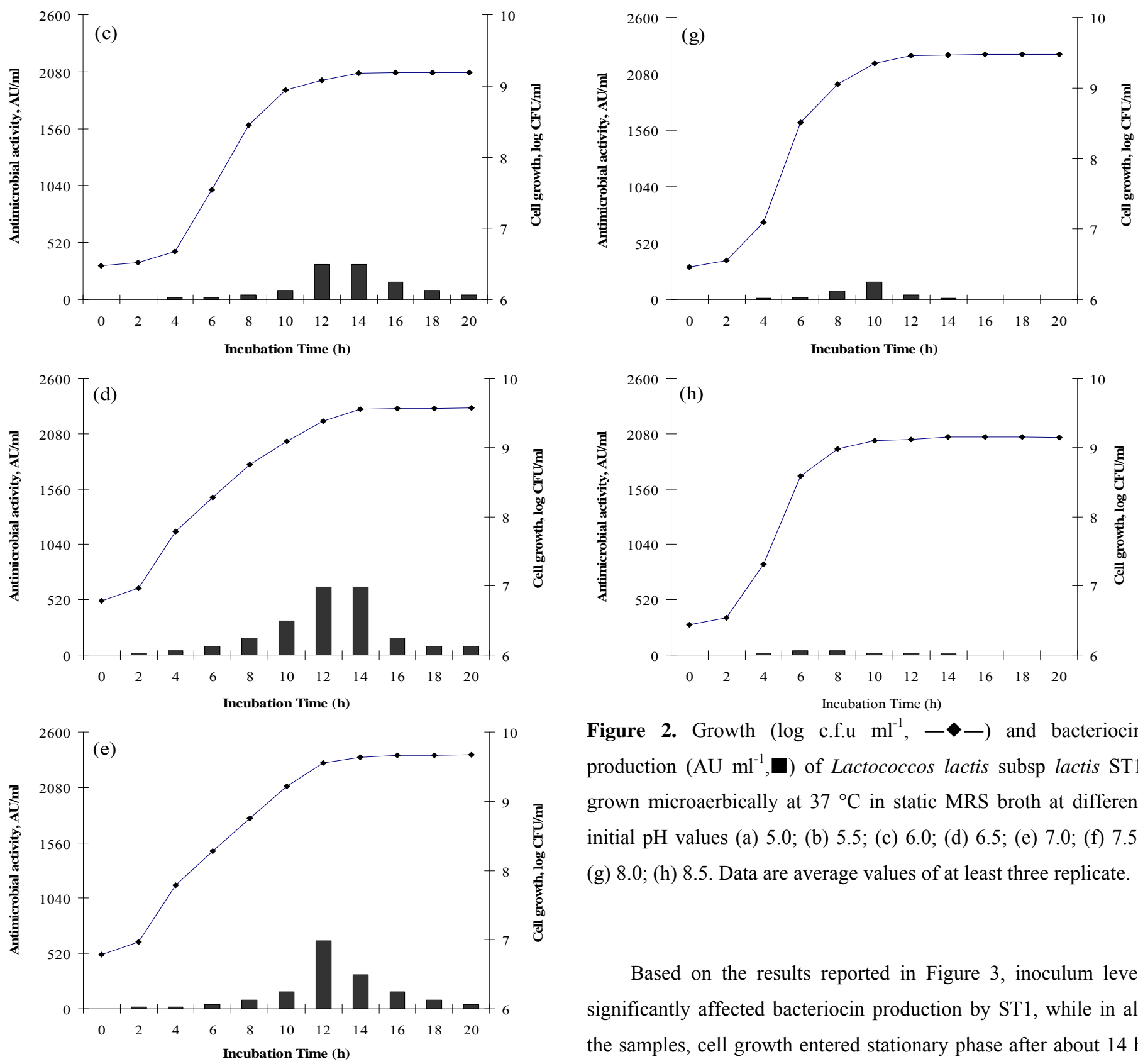

Figure 2. Growth ( $\log$ c.f.u $\mathrm{ml}^{-1},-\downarrow-$ ) and bacteriocin

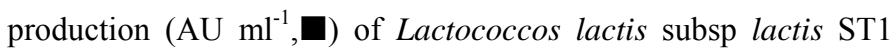
grown microaerbically at $37{ }^{\circ} \mathrm{C}$ in static MRS broth at different initial $\mathrm{pH}$ values (a) 5.0 ; (b) 5.5 ; (c) 6.0 ; (d) 6.5 ; (e) 7.0; (f) 7.5; (g) 8.0; (h) 8.5. Data are average values of at least three replicate.

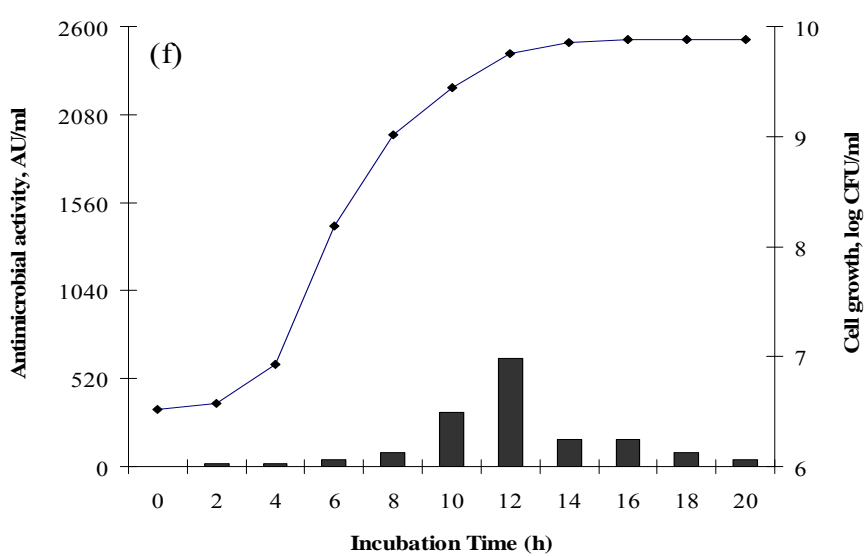

Based on the results reported in Figure 3, inoculum level significantly affected bacteriocin production by ST1, while in all the samples, cell growth entered stationary phase after about $14 \mathrm{~h}$ of incubation. Maximum bacteriocin activity and stability (640 $\mathrm{AU} / \mathrm{ml}$ ) were obtained at the lowest inoculum level (Fig. 3a). Aside from lower BLIS production, reduction in activity during the stationary phase was also achieved in the case of high initial cell density (Fig. 3c). These results are contradictory to those reported for Camobactetium piscicola LV17 (25), Lactobacillus plantarum $17.2 \mathrm{~b}$ (14). The positive effect of inoculum size on bacteriocin production was reported for these producer strains. Saucier et al. (25) and Himelbloom et al. (16) explained this phenomenon by the inducing effect of residual bacteriocin in the 
inoculum. While, Himelbloom et al. (16) claimed that inoculum size had no significant effect on the production of bacteriocin by L. acidophilus LF221 and C. piscicola A9b, respectively. Nevertheless, differences in the bacterial strains and production medium, as well as incubation conditions may be responsible for the inconsistency of these results.
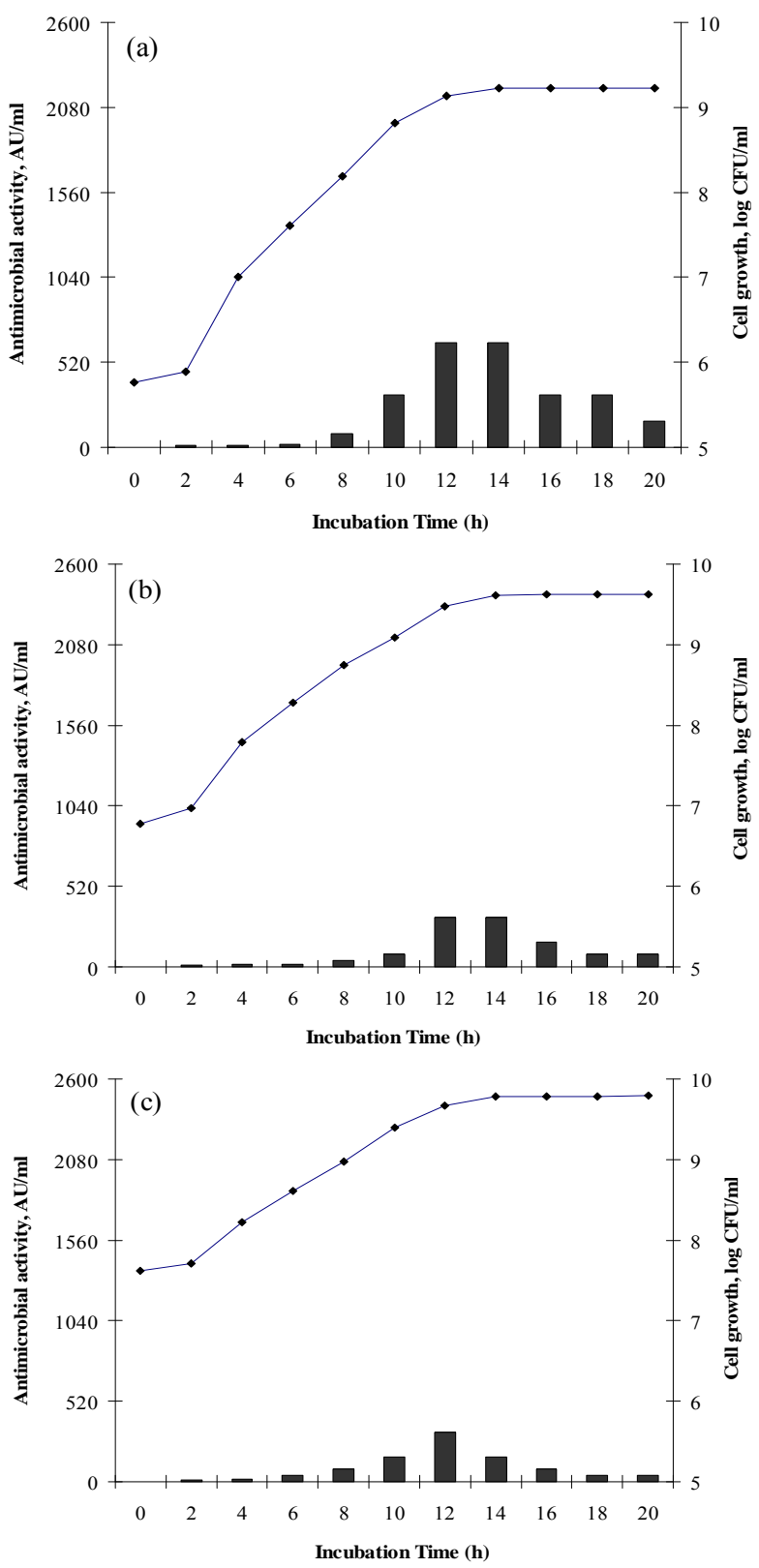

Figure 3. Growth (log c.f.u $\left.\mathrm{ml}^{-1},-\diamond-\right)$ and bacteriocin production $\left(\mathrm{AU} \mathrm{m} \mathrm{m}^{-1}, \mathbf{\square}\right)$ of Lactococcos lactis subsp lactis ST1 grown microaerbically at $37{ }^{\circ} \mathrm{C}$ in static MRS broth inoculated by different inoculum levels (v/v) (a) 0.1 ; (b) 1 ; (c) $10 \mathrm{ml} \mathrm{l}^{-1}$. Data are average values of at least three replicates.
The effect of different temperatures $\left(25,30\right.$ and $\left.37^{\circ} \mathrm{C}\right)$ on growth and bacteriocin production by ST1 is shown in Figure 4. The highest cell density was achieved at $37{ }^{\circ} \mathrm{C}(9.57 \mathrm{log}$ $\mathrm{CFU} / \mathrm{ml}$ ), while the optimum temperature for bacteriocin production was recorded as $30^{\circ} \mathrm{C}$. The inhibitory activity was reduced much further at $37{ }^{\circ} \mathrm{C}$, which may be related to an increase in proteolytic degradation or nutrition depletion. Maximum bacteriocin production at suboptimal growth temperatures has also been observed in other surveys $(9,14$, 30).

The results of bacteriocin production by L. lactis subsp. lactis ST1, under different incubation temperature are consistent with the previous studies by Cheigha et al., (9) and Todorov and Dicks (29) which showed the maximum nisin activity and maintenance at $30^{\circ} \mathrm{C}$ for Lactococcus lactis subsp. lactis A164 and Lactococcus lactis subsp. lactis ST34BR, respectively.
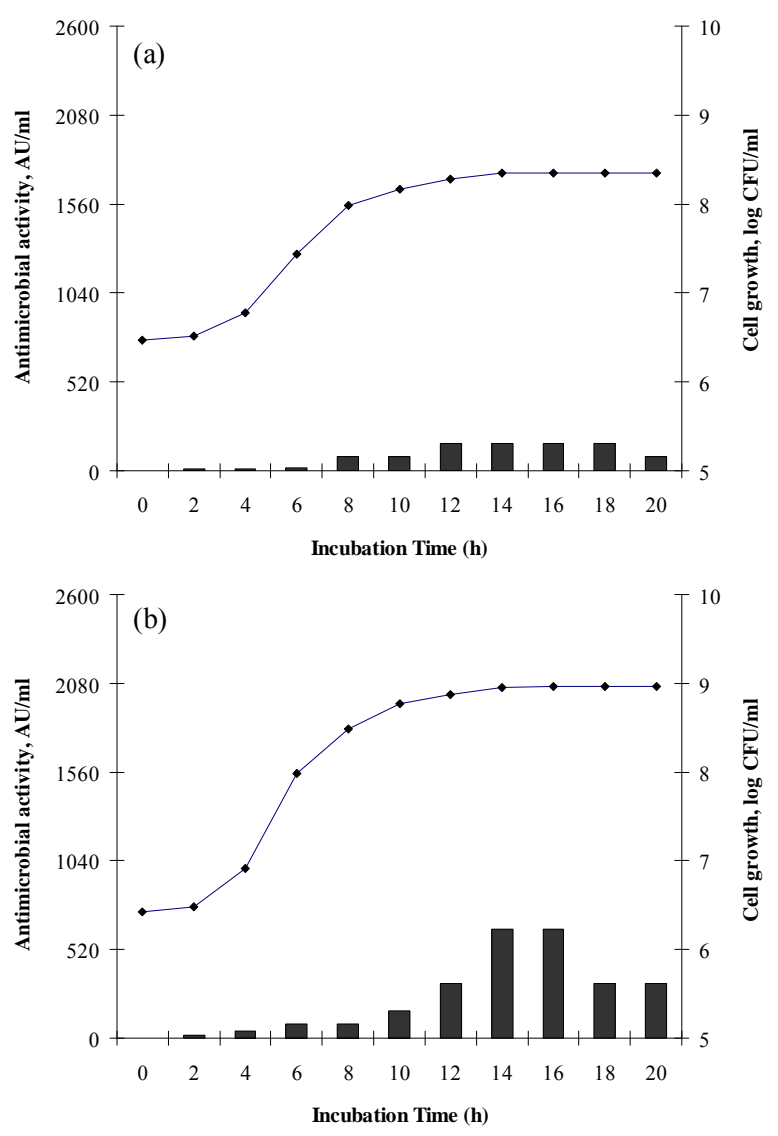


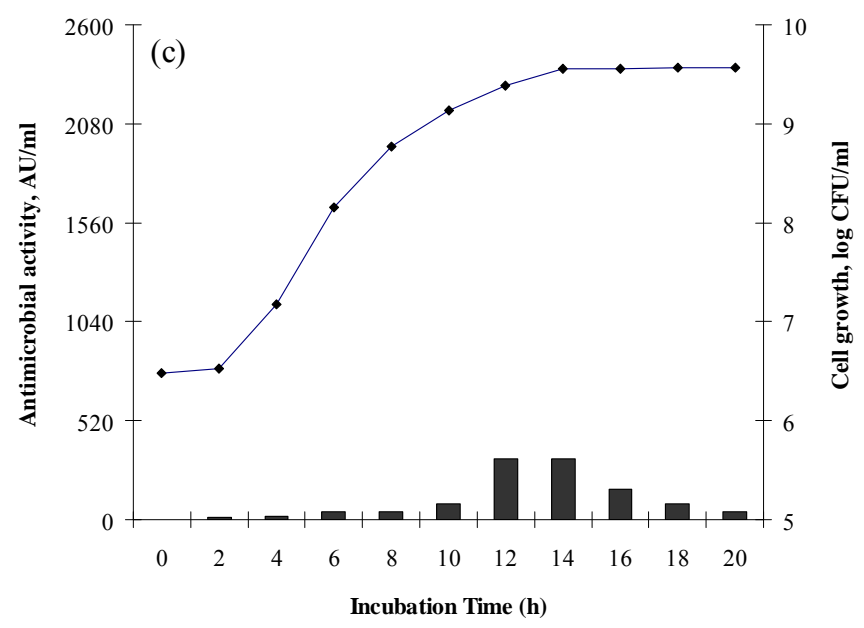

Figure 4. Growth (log c.f.u $\left.\mathrm{ml}^{-1},-\bullet-\right)$ and bacteriocin production $\left(\mathrm{AU} \mathrm{ml} \mathrm{m}^{-1}, \mathbf{\square}\right)$ of Lactococcos lactis subsp lactis $\mathrm{ST1}$ grown microaerbically in static MRS broth incubated at different temperature (a) $25^{\circ} \mathrm{C}$; (b) $30^{\circ} \mathrm{C}$; (c) $37{ }^{\circ} \mathrm{C}$. Data are average values of at least three replicates.

\section{Effect of Ultrasound, heat treatment, Tween and $\mathrm{pH}$ on desadsorption}

The effect of heat treatment and ultrasonic waves as well as Tween 80 at different $\mathrm{pH}$ conditions on the release of adsorbed bacteriocin from the cell wall of L. lactis subsp lactis ST1 is reported in Table 1. Alkaline $\mathrm{pH}$ was not tested because of its slight inactivating effect on the bacteriocin, as it has been determined in preliminary tests (data not shown).

Adjusting the $\mathrm{pH}$ of CFS to all acidic conditions, without any further treatment, did not influence the bacteriocin activity. Release was achieved after 5 and $10 \mathrm{~min}$, in all treated samples at $\mathrm{pH} 2$ and 4. No release was achieved when the samples were heated or exposed to ultrasonic waves at $\mathrm{pH} 6$. Increasing treatment period from 10 to 15 min was not favorable in all cases and resulted in lower activity that could be related to the inactivation of inhibitory compound during these conditions.

In whole, heating at acidic conditions was more effective than ultrasound shock. Heating at $100 \mathrm{C}$ in the presence of $0.5 \%$ Tween 80 resulted in $200 \%$ increase in bacteriocin activity but just $133.3 \%$ increase in the activity was observed after the ultrasound shock in the presence of Tween 80 .

Furthermore, Tween 80 played an important positive role in bacteriocin release and it caused higher activity after heating and ultrasound shock. It was obviously found that $\mathrm{pH} 2$ and $0.5 \%$ Tween 80 resulted in higher soluble activities while by increasing the $\mathrm{pH}$ of supernatants and omitting Tween80 from the CFS, release was reduced which was more pronounced in the case of ultrasonic shock.

In agreement with results of this study, it has been demonstrated that the solubility, stability and biological activity of nisin are dependent on the $\mathrm{pH}$ of the solution, and they increase drastically with the lowering of $\mathrm{pH}$ to 2 (1). Aymerich et al. (2) also introduced a combination of $\mathrm{pH}$ treatment with heat treatment essential for an increase in soluble activity. Yang et al. (36), on the other hand, indicated the influence of $\mathrm{pH}$ on the adsorption of bacteriocins onto cells and introduced $\mathrm{pH} 6.0$ for high adsorption and $\mathrm{pH} 2.0$ for maximum release. Hurst and Dring (18) also claimed that at a pH below 6.0 , more than $80 \%$ of nisin, produced by L. lactis subsp. lactis was present in the culture supernatant fluid.

In this report, the positive effect of heating at $\mathrm{pH} 2$ in the presence of $0.5 \%$ Tween 80 on bacteriocin release from the producer cell has been clearly shown. Aymerich et al. (2) and Todorov (34) also reported the positive effect of Tween on the adsorption reduction of bacteriocin on the bases of its capacity to prevent the adsorption of bacteriocin molecules.

Table 1. Effect of heat treatment, ultrasonic shock and Tween 80 at different $\mathrm{pH}$ conditions on the release of adsorbed nisin from the cell wall of $L$. lactis subsp lactis ST1.

\begin{tabular}{|c|c|c|c|c|c|c|c|c|c|}
\hline \multirow[b]{2}{*}{ CFS pH } & \multicolumn{9}{|c|}{ Bacteriocin activity increase (\%) } \\
\hline & \multicolumn{3}{|c|}{2} & \multicolumn{3}{|c|}{4} & \multicolumn{3}{|c|}{6} \\
\hline Time Courses (min) & 5 & 10 & 15 & 5 & 10 & 15 & 5 & 10 & 15 \\
\hline Treatment & & & & & & & & & \\
\hline No treatment & 0 & 0 & 0 & 0 & 0 & 0 & 0 & 0 & 0 \\
\hline Heating $\left(100^{\circ} \mathrm{C}\right)$ & 133.3 & 100.0 & - & 133.3 & 33.3 & - & 0 & 0 & - \\
\hline Heating+Tween 80 & 200.0 & 166.7 & 0 & 166.7 & 100.0 & - & 0 & 0 & - \\
\hline Ultrasound (28kHz) & 100.0 & 100.0 & 33.3 & 66.7 & 33.3 & - & 0 & 0 & - \\
\hline Ultrasound+Tween 80 & 133.3 & 66.7 & - & 100.0 & 66.7 & - & 0 & - & - \\
\hline
\end{tabular}




\section{CONCLUSION}

Lactococcus lactis subsp lactis ST1, isolated from goat milk, was tested for bacteriocin production kinetics at different growth conditions. This study indicated that the conditions resulting in higher levels of growth frequently favor bacteriocin production by ST1. Higher cell growth and inhibitory activity was detected in capnophilic and microaerophilic growth conditions while aerobiosis resulted in lower cell growth and bacteriocin production. On the other hand, higher bacteriocin activity was detected at suboptimal growth temperatures and the lowest initial cell count resulted in the highest bacteriocin production. The study also demonstrated bacteriocin activity increase after heating the culture at acidic condition and after ultrasound shock. This could be described by the release of adsorb bacteriocin from the cell wall of the producer, particularly in the presence of $0.5 \%$ Tween 80 . Thus, ultrasound shock can be used as an alternative method for heating in order to release bacteriocin from the producer cell wall. Bacteriocin activity reduced at stationary growth phase in all test conditions. This reduction was more pronounced in favorable growth condition. On the other hand, as the culture became more acidic at such growth phase and conditions, our finding expected higher levels of release and inhibitory activity in these conditions while the expectation did not come true, and a considerable reduction was detected instead. Thus, this decrease in activity cannot be explained by bacteriocin desorption, and the situatuation needs to be analyzed and observed through a different base. Based on the highest cell growth and bacterial activity under desirable growth conditions, this reduced inhibitory activity could be related to nutrition depletion, protein degradation and/or deferent effect of low $\mathrm{pH}$ on bacteriocin production.

\section{REFERENCES}

1. Arauza, L.J.; Jozalaa, A.F.; Mazzolab P.G.; Penna, T.C.V. (2009). Nisin biotechnological production and application: a review. Trends. Food. Sci. Tech. 20, 146-154
2. Aymerich, T.; Artigas, M.G.; Garriga, M.; Monfort, J.M.; Hugas, M. (2000). Effect of sausage ingredients and additives on the production of enterocins A and B by Enterococcus faecium CTC492 Optimization of in vitro production and anti-listerial effect in dry fermented sausages. $J$. Appl. Microbiol. 88, 686-694.

3. Batdorj, B.; Dalgalarrondo, M.; Choiset, Y.; Pedroche, J.; Metro, F.; Prevost, H.; Chobert, J.M.; Haertle, T. (2006). Purification and characterization of two bacteriocins produced by lactic acid bacteria isolated from Mongolian airag. J. Appl. Microbiol. 101, 837-848.

4. Benkerroum, N.; Oubel, H.; Zahar, M.; Dlia, S.; Filali-Maltouf, A. (2000). Isolation of a bacteriocin-producing Lactococcus lactis subsp. lactis and application to control Listeria monocytogenes in Moroccan jben. J. Appl. Microbiol. 89, 960-968.

5. Bhunia, A.K.; Johnson, M.C.; Ray, B.; Kalchayanand, N. (1991). Mode of action of pediocin $\mathrm{AcH}$ from Pediococcus acidilactici $\mathrm{H}$ on sensitive bacteria strains. J. Appl. Bacteriol. 70, 25-33.

6. Bonade, A.; Murelli, F.; Vescovo, M.; Scolari, G. (2001). Partial characterization of a bacteriocin produced by Lactobacillus helveticus. Lett. Appl. Microbiol. 33, 153-158

7. Cabo, M.L.; Murado, M.A.; Gonza'lez, M.P.; Pastoriza, L. (2001). Effects of aeration and $\mathrm{pH}$ gradient on nisin production. A mathematical model. Enzyme. Microb. Tech. 29, 264-273.

8. Callewaert, R.; Holo, H.; Devreese, B.; Van Beeumen, J.; Nes, I.; De Vuyst, L. (1999). Characterization and production of amylovorin L471, a bacteriocin purified from Lactobacillus amylovorus DCE 471 by a novel three-step method. Microbiology. 145, 2559-2568.

9. Cheigh C.I.; Choia, H.J.; Parka, H.; Kima, S.B.; Kooka, M.C.; Kimb, T.S.; Hwanga, J.K..; Pyuna, Y.R. (2002). Influence of growth conditions on the production of a nisin-like bacteriocin by Lactococcus lactis subsp. lactis A164 isolated from kimchi. J. Biotechnol. 95, 225-235.

10. Choi, H.J.; Cheigh, C.I.; Kim, S.B.; Pyun, Y.R. (2000). Production of a nisin-like bacteriocin by Lactococcus lactis subsp. lactis A164 isolated from Kimchi. J. Appl. Microbiol. 88, 563-571.

11. Cleveland, J.; Montville, T.J.; Nes, I.F.; Chikindas, M.L. (2001). Review article; Bacteriocins: safe, natural antimicrobials for food preservation. Int. J. Food. Microbiol. 71, 1-20

12. De Man, J.D.; Rogosa, M.; Sharpe, M.E. (1960). A medium for the cultivation of lactobacilli. J. Appl. Bact. 23, 130-135.

13. De Vuyst, L.; Vandamime, E.J. (1992). Influence of the carbon source on nisin production in Lactococcus lactis ubsp. lactis batch fermentations. J. Gen. Microbiol. 138, 571-578.

14. Delgado, A.; Arroyo L'opez, F.N.; Brito, D.; Peres, C.; Fevereiro, P.; Garrido-Fern'andez, A. (2007). Optimum bacteriocin production by Lactobacillus plantarum $17.2 \mathrm{~b}$ requires absence of $\mathrm{NaCl}$ and apparently follows a mixed metabolite kinetics. J. Biotechnol. 130, 193-201.

15. Dmitriev, B.; Toukach, F.; Ehlers, S. (2005). Towards a comprehensive view of the bacterial cell wall. Trends. Microbiol. 13, 569-574. 
16. Himelbloom, B.; Nilsson, L.; Gram, L. (2001). Factors affecting production of an antilisterial bacteriocin by Carnobacterium piscicola strain $\mathrm{A} 9 \mathrm{~b}$ in laboratory media and model fish systems. J. Appl. Microbiol, 91, 506-513.

17. Hirsch, A. (1951). Growth and nisin production of a strain of Streptococcus lactis. J. Gen. Microbiol. 5, 208 -221.

18. Hurst, A.; Dring, G.J. (1968). The relation of the length of lag phase of growth to the synthesis of nisin and other basic proteins by Streptococcus lactis grown under different cultural conditions. J. Gen. Microbiol. 50, 383-390.

19. Leroy, F.; Vankrunkelsven, S.; De Greef, J.; De Vuyst, L. (2003). The stimulating effect of a harsh environment on the bacteriocin activity by Enterococcus faecium RZS C5 and dependency on the environmental stress factor used. Int. J. Food. Microbiol. 83, 27-38.

20. Mitra, S.; Chakrabartty, P.K.; Biswas, S.R. (2005). Production and Characterization of Nisin-Like Peptide Produced by a Strain of Lactococcus lactis Isolated from Fermented Milk. Curr. Microbiol. 51, 183-187.

21. Mitra, S.; Chakrabartty, P. K.; Biswas, S. R. (2007) Production of Nisin $\mathrm{Z}$ by Lactococcus lactis Isolated from Dahi, Appl. Biochem. Biotechnol. $143,41-53$.

22. Onda, T.; Yanagida, F.; Tsuji, M.; Shinohara, T.; Yokotsuka, K. (2003). Production and purification of a bacteriocin peptide produced by Lactococcus sp. strain GM005, isolated from Miso-paste. Int. J. Food. Microbiol. 87, 153 - 159 .

23. Powell, J.E.; Witthuhn, R.C.; Todorov, S.D.; Dicks, L.M.T. (2007). Characterization of bacteriocin ST8KF produced by a kefir isolate Lactobacillus plantarum ST8KF. Int. Dairy J. 17, 190-198.

24. Rodgers, S. (2001). Preserving non-fermented refrigerated foods with microbial cultures - a review, Trends. Food .Sci. Tech. 12, 276-284.

25. Saucier, L.; Poon, A.; Stiles, M.E. (1995). Induction of bacteriocin in Carnobacterium piscicola LV17. J. Appl. Bacteriol, 78, 684-690.

26. Settanni, L.; Valmorri, S.; Suzzi, G.; Corsetti, A. (2008). The role of environmental factors and medium composition on bacteriocin like inhibitory substances (BLIS) production by Enterococcus mundtii strains. Food Microbiol. 25, 722- 728.

27. Sousa, M.N.B.; Mendes, E.N.; Apolonio, A.C.M.; Farias, L.D.M.;
Magalha, E.S. (2010). Bacteriocin production by Shigella sonnei isolated from faeces of children with acute diarrhea. APMIS. 118, 125-135

28. Tabatabaie, F.; Mortazavi, A. (2008). Studying the Effects of Ultrasound Shock on Cell Wall Permeability and Survival of Some LAB in Milk, World. Appl. Sci. J. 3, 119-121.

29. Todorov, S.D.; Dicks, L.M.T. (2004). Influence of growth conditions on the production of a bacteriocin by Lactococcus lactis subsp. lactis ST34BR, a strain isolated from barley beer, J. Basic. Microb. 44, 305316.

30. Todorov, S.D.; Dicks, L.M.T. (2004). Screening of lactic-acid bacteria from south African barley beer for the production of bacteriocin-like compounds, Folia Microbiol, 49, 406-410.

31. Todorov, S.D.; Dicks, L.M.T. (2006). Screening for bacteriocinproducing lactic acid bacteria from boza, a traditional cereal beverage from Bulgaria: comparison of the bacteriocins. Process. Biochem. 41, $11-19$.

32. Todorov, S.D.; Nyati, H.; Meincken, M.; Dicks, L.M.T. (2007). Partial characterization of bacteriocin AMA-K, produced by Lactobacillus plantarum AMA-K isolated from naturally fermented milk from Zimbabwe. Food Control. 18, 656-664.

33. Todorov, S.D.; van Reenen, C.A.; Dicks, L.M.T. (2004). Optimization of bacteriocin production by Lactobacillus plantarum ST13BR, a strain isolated from barley beer. J. Gen. Appl. Microbiol. 50, 149-157

34. Todorov, S.D. (2008). Bacteriocin Production by Lactobacillus plantarum AMA-K Isolated from AMASI, a zimbabwean Fermented Milk Product and Study of the Adsorption of Bacteriocin AMA-K to Listeria SP. Braz. J. Microbiol. 39, 178-187.

35. Wolf-Hall, C. E.; Gibbons W. R.; ; Bauer, N. A. (2009). Development of a low-cost medium for production of nisin from Lactococcus lactis subsp. lactis. World. J. Microbiol. Biotechnol. 25, 2013-2019.

36. Yang, R.; Johnson, M.C.; Ray, B. (1992). Novel method to extract large amounts of bacteriocins from lactic acid bacteriat. Appl. Environ. Microb. 58, 3355-3359.

37. Zamfir, M.; Callewaert, R.; Cornea, P.C.; De Vuyst, L. (2000). Production kinetics of acidophilin 801, a bacteriocin produced by Lactobacillus acidophilus IBB 801. FEMS Microbiol. Lett. 190, 305308. 